\title{
Excalfactoria and a bird and word book to keep
}

BOOK TITLE:

Latin for birdwatchers

\section{BOOK COVER:}

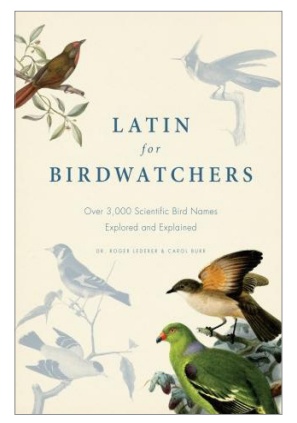

AUTHORS:

Roger Lederer and Carol Burr

ISBN:

9781775840930

\section{PUBLISHER:}

Struik Nature, Cape Town, ZAR220

\section{PUBLISHED:}

2014

\section{REVIEW TITLE:}

Excalfactoria and a bird and word book to keep you warm

\section{REVIEWER:}

Duncan Mitchell ${ }^{1,2}$

EMAIL:

duncan.mitchell@wits.ac.za

\section{AFFILIATIONS:}

${ }^{1}$ Rand Barbets Bird Club of BirdLife South Africa, Johannesburg, South Africa 2Emeritus Professor, School of Physiology, University of the Witwatersrand, Johannesburg, South Africa

\section{POSTAL ADDRESS:}

Brain Function Research Group, School of Physiology, Faculty of Health Sciences, University of the Witwatersrand, Private Bag 3, Wits 2050, South Africa

\section{HOW TO CITE:}

Mitchell D. Excalfactoria and a bird and word book to keep you warm. S Afr J Sci. 2014;110(9/10), Art. \#a0077, 1 page. http://dx.doi. org/10.1590/sajs.2014/a0077

(C) 2014. The Authors. Published under a Creative Commons Attribution Licence.

\section{you warm}

Chico, California, bordered by almond orchards and home to the US YO-Yo Museum, seems an unlikely place to find an erudite husband-and-wife team who love birds, and words, and Latin. Roger Lederer and Carol Burr both have PhDs and both are Emeritus Professors at California State University, Chico - he of Biological Sciences and she of English. On his website, Lederer says he 'knows exactly what birds you will find anywhere in the world'; he has travelled to over 100 countries. He has written five previous books on birds, and a 1984 textbook on Ecology and Field Biology. Burr is using her retirement from teaching English and Women's Studies to paint and draw, in oils, water colours, pen and coloured pencils (the medium that she has used in illustrating Latin for Birdwatchers).

Latin for Birdwatchers sets out to explore and explain 3000 scientific bird names, listed alphabetically. It does not claim to be comprehensive: there are about 20000 bird names. Those scientific names are the Linnaean binomial names, that is, the paired names of genus and species in the system set up by Carl Linnaeus (1707-1778) for naming everything alive. Although BirdLife South Africa works hard to promote the use of these names, birdwatchers tend to show less interest in Linnaean binomials than do, for example, tree watchers, but they are the only definitive names for birds (and trees). Most Linnaean binomials for birds are Latin-derived constructs, but enough, and especially those for African bird species, are Greek-derived to have justified 'and Greek' in the book's title: meleagris, as in Numida meleagris (helmeted guineafowl) is the Greek word for guinea fowl and Tyto, as in Tyto alba (barn owl), the Greek word for owl. Some names are derived from other languages. Pitta - as in Pitta angolensis (African pitta) - is an Indian word meaning 'little bird'. The kori in Ardeotis kori (kori bustard) comes from its Setswana name kgôri. For all the Linnaean binomials listed, the authors offer an easy-to-interpret pronunciation as if in post-Renaissance Latin, with the appropriate syllable emphasised: mel-ee-AH-gris and TI-to.

Most Linnaean binomials are descriptive of the bird's biology, and for each of those listed the authors explain the derivation. To cover 3000 names, their explanations necessarily have to be brief, although they have expanded a few in boxes that they have called 'Latin in action' (Picus, after whom the woodpecker family Picidae was named, was a king in Roman mythology turned into a woodpecker by the witch Circe). Wildlife author Richard Conniff, who reviewed the book, otherwise favourably, in May 2014 for the Wall Street Journal, complained that some explanations were too brief to be satisfactory. (The US version that he reviewed was called Latin for Bird Lovers; South Africans apparently are allowed to 'watch' birds but not to 'love' them.) I did not find the explanations unsatisfactorily brief; they are more comprehensive, for example, than the explanations in the 'big Roberts'1, which, of course, admirably serves many purposes other than explaining binomials. Some Linnaean binomials are not descriptive but acknowledge a person associated with a species, and the person celebrated is identified in a phrase: Neergaard ('recruiter for Witwatersrand mines') of Neergaard's sunbird Cinnyris neergaardi is recognised, as is Barlow ('South African businessman') of Barlow's lark Calendulauda barlowi and Vigors ('Irish secretary of the Zoological Society of London') of the Karoo korhaan Eupodotis vigorsii, but not Stierling of Stierling's wren-warbler Calamonastes stierlingi or Rüppell of Rüppell's vulture Gyps rueppellii. Some Latin names are onomatopoeic: Pitohui as in Pitohui dichrous (hooded pitohui, a poisonous oriole-like bird from New Guinea) 'is the sound made after a human tastes and immediately rejects the poisonous bird', and Tockus, the hornbill genus, comes from 'a Portuguese imitation of the bird's call'. Here are some of the descriptive Latin names related to birds well known to South African birdwatchers: 'cista, a wooden basket, and colo, dwell', describing the nesting habits of cisticolas; Ispidina 'from hispidus, rough, shaggy, hairy, as in Ispidina picta' (African pigmy kingfisher); Mirafra in Mirafra africana (rufous-naped lark, called Mirafra mirafra in the book) from 'miras, wonderful, and afra, African'; 'Musophaga, from musa, banana, and phagus, eater of, as in Musophaga rossae' (Ross's turaco).

Just the list of Linnaean binomial names would have entertained me sufficiently, but that is not where Lederer and Burr left their book. They added two-page biosketches of 11 'famous birders', including John Gould (1804-1881), after whom 24 bird species have been named (more than after anyone else), and the real James Bond (1900-1989), after whom lan Fleming named 007 . There are 20 one-page 'genus profiles', including the Laniidae, from lanius, Latin for 'butcher', amongst which are the fiscals, from the Afrikaans fiskaal, meaning, according to Lederer and Burr, 'a public official, particularly a hangman'. There are eight two-page essays on bird biology, containing interesting information that even experienced birdwatchers may not know. And then every page has one or more illustrations by Burr, attractively drawn not so much for ornithological accuracy but, as she herself said in an interview on Chico's Northstate Public Radio, to try to capture the personality and aesthetics of the bird.

The book has been produced beautifully by Quid Publishing in the UK for Struik Nature. It has a textured hard cover, is a comfortable size, and is printed on elegant fulvus paper. I found some repetition in the grammar and a few typographical errors, which easily can be fixed in later editions, and do not intrude in this edition. If you like birds and words, and especially if you like Latin and Greek, read Latin for Birdwatchers cover to cover, or explore a favourite genus or historical ornithologist, or absorb a bird's personality from an illustration, or just take a lucky dip. I do not think that the book will work well in electronic format. This is a book that you need to hold in your hands, to keep you warm. And I'll leave it to you to discover why the king quail is called Excalfactoria chinensis.

\section{Reference}

1. Hockey PAR, Dean WRJ, Ryan PG. Roberts birds of southern Africa. 7th ed. Cape Town: The Trustees of the John Voelcker Bird Book Fund; 2005. 